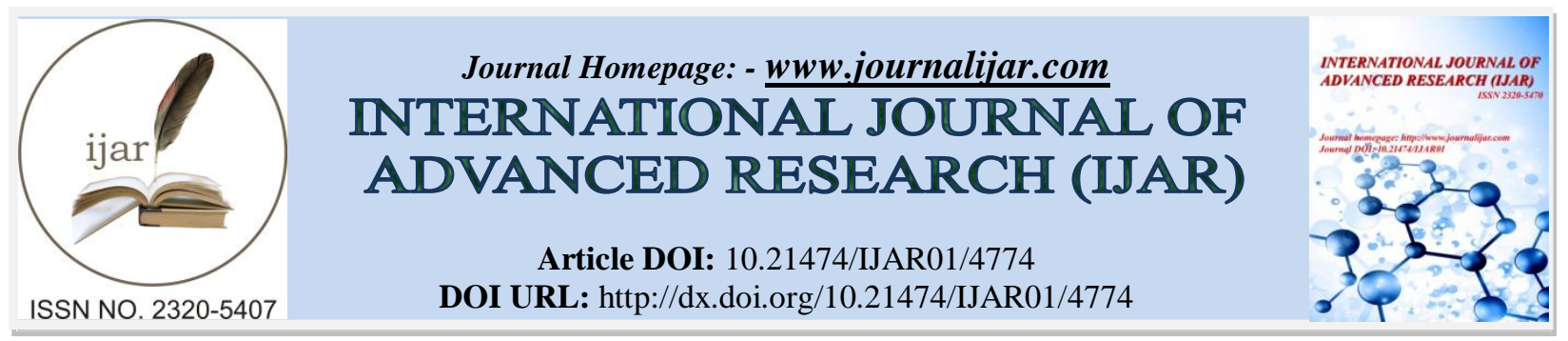

RESEARCH ARTICLE

\title{
AN INVESTIGATION INTO THE POLYMORPHISM OF TPO GENE AND ITS ASSOCIATION WITH HYPOTHYROIDISM IN KASHMIRI POPULATION.
}

\author{
Gousia Qayoom Mir ${ }^{1}$, Bashir Ahmad Ganai ${ }^{2}$, Shariq Rashid Masoodi ${ }^{3}$, Shagufta Sheikh ${ }^{1}$ and Akbar \\ Masood $^{1}$. \\ 1. Department of Biochemistry, University of Kashmir, Hazratbal, Srinagar, India. \\ 2. Center of Research for Development (CORD), University of Kashmir, Hazratbal, Srinagar, India. \\ 3. Sheri Kashmir Institute of Medical Sciences (SKIMS), Srinagar.
}

\section{Manuscript Info}

\section{Manuscript History}

Received: 7 May 2017

Final Accepted: 9 June 2017

Published: July 2017

Key words:-

Thyroid stimulating hormone receptor gene, Thyroid peroxidase gene, autoimmune thyroid disorder.

\section{Abstract}

TPO gene is pivotal for the normal functioning of the thyroid gland. A mutation in this gene is associated with several disorders of thyroid hormonogenesis including hypothyroidism. In this study, we investigated the role of TPO codon T2229C genetic variants in hypothyroidism. Blood samples were taken from a total of 445 participants (220 cases and 225 healthy subjects), aged 16-70 years, which were randomly selected from among the Kashmiri population. All the necessary information on the thyroid disease and other lifestyle and environmental exposure were gathered by questionnaire and the patient's endocrinologist or general practitioner verified the diagnosis. The polymorphism of the codon T2229C of the TPO gene was identified by polymerase chain reaction-based restriction analysis and direct sequencing.

Statistical analysis suggested a single nucleotide polymorphism that is a C-to-T substitution at codon 2229 of the TPO gene. The frequency of its variant genotype T (combined CT and TT genotype) as noted in cases was associated with a borderline increased risk of hypothyroidism $(\mathrm{OR}=1.62 ; 95 \% \mathrm{CI}=1.07-2.43 ; \mathrm{P}=0.02)$ as compared to healthy subjects.

Our study also observed a positive association of the TPO gene polymorphism with certain environmental exposures, lifestyle changes, smoking habits and in subjects with high basal metabolic Index (BMI). This observation suggests a possible role of this polymorphism in the etiology of hypothyroidism in Kashmir.

Copy Right, IJAR, 2017,. All rights reserved.

\section{Introduction:-}

The thyroid gland is very necessary for the normal functioning of the human body as it plays a crucial role in almost all the tissues of the human body through its secretion of two major thyroid hormones; thyroxine $\left(\mathrm{T}_{4}\right)$ and 3-3'-5-triiodo thyronine $\left(\mathrm{T}_{3}\right)(1,2)$. These thyroid hormones control growth, differentiation, regulation of metabolism and other physiological functions in the human body (3). Under normal conditions, thyroid gland output is about $90 \%$ of $\mathrm{T}_{4}$ and $10 \% \mathrm{~T}_{3}(4)$. 
An underproduction of the thyroid hormones $\mathrm{T}_{3}$ and $\mathrm{T}_{4}$ leads to hypothyroidism. It may happen as a result of congenital thyroid abnormalities, AITD (auto-immune thyroid disorders) where the immune system mistakes healthy thyroid tissue as a foreign body and attacks it, such as Hashimoto's thyroiditis (5) the surgical removal of the thyroid gland as a treatment for severe hyperthyroidism and/or thyroid cancer. The prevalence of thyroid disorders as seen throughout the world is $25 \%$ in females and $0.6 \%$ in males. It has been estimated that about 42 million people in India have thyroid dysfunction (6). A hospital based study on the prevalence of thyroid disorders in Srinagar reported an overall $40.36 \%$ of Kashmir population suffering from thyroid disorders (7). Subclinical hypothyroidism was found to be the most prevalent thyroid disorder (33.7\%) followed by an overt hypothyroidism $(5.1 \%)$ and hyperthyroidism $(1.63 \%)$. In women, the maximum prevalence of subclinical hypothyroidism was seen in the reproductive age group. According to the age-wise prevalence of thyroid disorders, maximum cases of subclinical hypothyroidism belong to 21-30 years age group. With respect to overt hypothyroidism, maximum cases were observed between the age 21 and 50 years.

The Jammu and Kashmir state is situated along the Himalayan range and is surrounded by the mountains. It is reported that in mountainous areas and hilly region, living things are deficit of iodine content due to years washing of the soil by heavy rains and recurrent floods. (8). Diet has also been observed to play an important role in the development of thyroid disorder. The staple diet of Kashmir valley is rice, fresh green leafy vegetables and nonvegetarian foods (9). There are some food types that contain goitrin, thiocyanates and flavonoids called goitrogens or goitrogenic foods, for example, turnip, radish, cabbage, cauliflower, corn, soy, etc., which are known to cause goiter and other disorders of the thyroid gland. The consumption of such food items is said to make it difficult for the thyroid gland to absorb iodine by decreasing the activity of the enzyme thyroid peroxidase, which promotes the insertion of iodine into thyroid hormone $(10,11)$. In healthy adult subjects, thyroid stimulating hormone (TSH) has considerable variability between individuals, whereas this variability is much less in the same individual when TSH is measured repeatedly over an extended period of time (12). Therefore, understanding variation in TSH levels and the genes responsible may be particularly important in a population at risk for abnormal TSH levels. Thyroid peroxidase (TPO) is the key enzyme in the synthesis of thyroid hormones and its (TPO) mutations is one of the most common causes of thyroid dyshormonogenesis. TPO is a $110 \mathrm{KD}$ glycoprotein that uses heme as a cofactor (13). It has 933 amino acids, which are encoded by mRNA of 3048 nucleotides (14). The TPO gene is located on the short arm of chromosome 2, locus 2 p25 consists of 17 exons $(15,16)$. Autoimmune thyroid diseases may occur due to several reasons, such as total absence of TPO activity, non-binding of cofactor heme to TPO, inability to interact with the Tg substrate and abnormal subcellular localization (17). There are no data for the codon T2229C of the TPO gene polymorphisms among hypothyroidic patients in Kashmir valley. The current study was designed to determine whether this TPO gene polymorphism is associated with hypothyroidism in Kashmir study population.

\section{Materials and Methods:-}

This study was approved by the Human Research Ethics Committee at the Sheri Kashmir Institute of Medical Sciences and Informed consent was obtained from each subject. The subjects for the current case-control study were 445 adults ( 220 cases and 225 controls), These include 174 men and 271 women, aged 16-70 years, who were randomly selected from among the Kashmiri population. Subjects with clinically confirmed thyroid disorders (hypothyroidic) were assessed and included as cases in the study while as controls were healthy individuals with no history of any disease/disorder. Subjects with any type of malignancy, diabetes, high cholesterol levels and abnormal lipid profile and those who do not want to participate were excluded. Controls were individually matched to cases in all respects (age \pm 10 years). Samples were obtained from the community centers and other departments of SKIMS. At study entry, all subjects completed a questionnaire, covering data on demographic, biochemical factors, smoking habits, the basal metabolic index including weight and height, type of food intake etc.

\section{Genotypic Analysis:-}

The Genomic DNA was extracted from whole blood samples using modified phenol - chloroform method (18). The polymorphism of the TPO gene codon T2229C was determined by polymerase chain reaction-restriction fragment length polymorphism (PCR-RFLP) analysis. The primers for the TPO gene codon T2229C along with their PCR cycling conditions, restriction enzymes, and restriction digestion fragments are listed in Table 1. PCR was performed in a total volume of $25 \mu \mathrm{l}$ carried out in $0.2 \mathrm{ml}$ PCR tubes (axygen). The PCR reaction mixture consisted

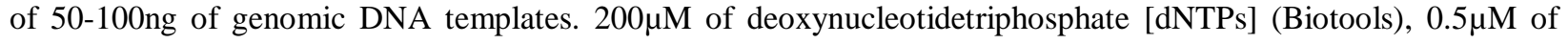
each primer (Fermentas), $2.5 \mathrm{mM} \mathrm{MgCl} 2$ and $2.0 \mathrm{U}$ of Taq Polymerase with $2.5 \mu 110 \mathrm{x}$ reaction buffer (Biotools). The codon 2229 SNP in the exon 12 of TPO gene was also assessed by the PCR technique, thereby yielding $177 \mathrm{bp}$ product (Fig. A). The PCR product was subjected to restriction enzyme analysis by digestion at $37^{\circ} \mathrm{C}$ for overnight 
with 1 unit of the Eco571 restriction endonuclease. $10 \mu \mathrm{l}$ of the digested product was then analyzed by loading onto a 3\% agarose gel stained with ethidium bromide and separated by electrophoresis. The PCR-RFLP results obtained from the study genes were validated by direct sequencing PCR products (Sequence scanner software BioEdit was used for comparing sequences between the original PubMed gene sequence) (Fig. B \& C).

Table 1:- List of Primers, PCR conditions, restriction enzymes, and restriction digestion fragments of the genes of interest.

\begin{tabular}{|l|l|l|l|l|}
\hline Gene & Primers & PCR conditions & RE$^{*}$ & $\mathbf{A P}^{\mathbf{a}} \& \mathbf{D P}^{\mathbf{b}}\left(\mathbf{b p}^{\mathbf{c}}\right)$ \\
\hline \multirow{3}{*}{ TPO } & FP- 5'- CTGTCTCGGGTCATCTGT G -3' & $95^{\circ} \mathrm{C}-5 \mathrm{~min}$ & \multirow{2}{*}{ Eco } & $\mathrm{AP}=177$ \\
& RP-5'-GTAACGTGGTGTGAGAGGAGAC-3' & $60^{\circ} \mathrm{C}-60 \mathrm{sec} 35$ & 571 & $\mathrm{~W}=177$ \\
& & cycles & & $\mathrm{H}=177,95,82$ \\
& & $72^{\circ} \mathrm{C}-1 \mathrm{~min}$ & & $\mathrm{M}=95,82$ \\
\hline
\end{tabular}

*RE - Restriction enzyme used.

${ }^{a} A P$ - Amplified products, ${ }^{b} D P$ - Digested products, ${ }^{c} b p$ - base pairs

$W$ - Wild allele, $H$ - Heterozygous mutant, $M$ - Mutant allele

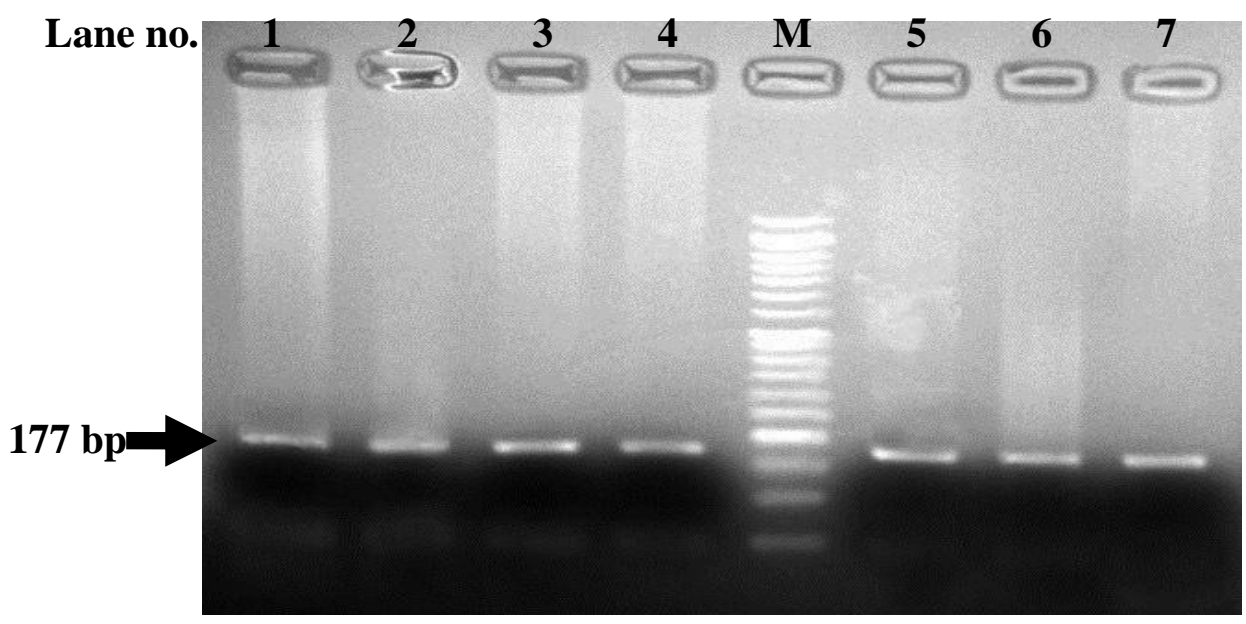

Figure A: - Representative gel picture (1.5\%) showing 177 bp PCR product of TPO gene, lane 1-7 represent amplicon of codon T2229C and lane $\mathrm{M}(50 \mathrm{bp})$ represents a molecular weight marker.

Lane no: 1 TT 2 CT 3 CC $4 \quad$ M 5 CC 6 CT 7 CC 8 CC 9 TT

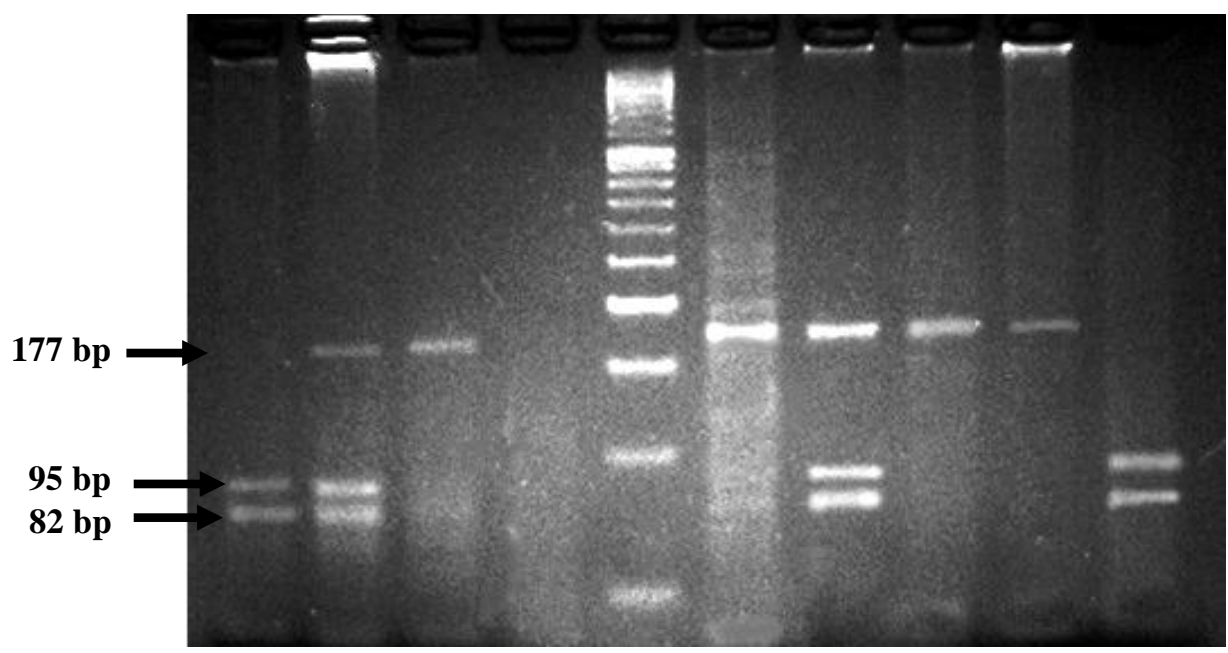

Figure B: - Representative gel picture showing RFLP analysis of TPO gene Codon T2229C: Lane no. 2and 6 - CT (heterozygous variant genotype), Lane no. 3, 5, 7 and $8-\mathrm{CC}$ (wild/normal genotype) and Lane no. 1 and 9 represent homozygous mutant genotype TT. Lane M is the DNA size marker (50bp). 
(A)
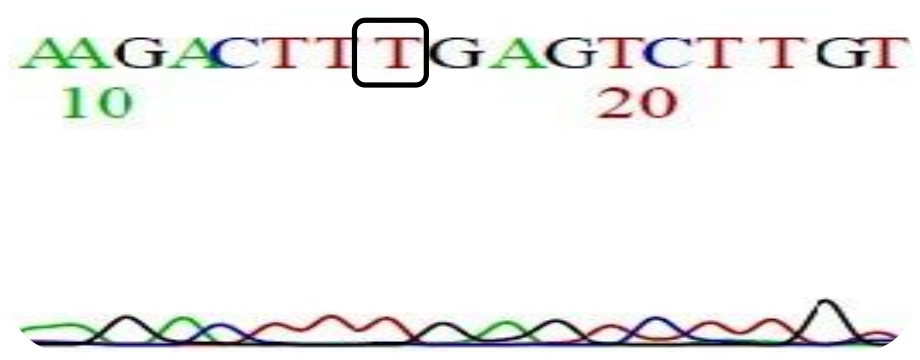

Mutant Genotype (T/T)

(B)

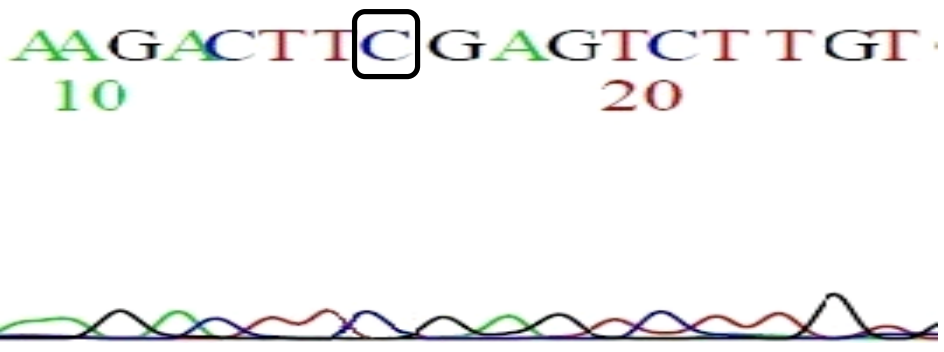

Wild Genotype (C/C)

Figure C:- Chromatogram of TPO codon T2229Cgenotype showing; (A): C/T transition and (B): C/C genotype.

\section{Statistical Analysis:-}

The allelic frequencies were estimated by gene counting and genotypes were scored. The chi-square $\left(\chi^{2}\right)$ test was used to examine differences in demographic variables, distribution of genotypes with those expected for a population in the Hardy-Weinberg equilibrium and to test the significance of the differences of observed alleles and genotypes between groups. The odds ratios (ORs) and 95\% confidence intervals (CIs) were calculated by using a Yates' continuity corrected chi-square $\left(\chi^{2}\right)$ test and based on this calculation, the risk of thyroid disorders was estimated. Statistical analysis of the data was performed using Graph Pad Prism version 6.0 software. The criterion for statistical significance was defined as $\mathrm{P}<0.05$.

\section{Results:-}

In this study, a total of 445 blood samples were included, 220 thyroid disorder cases and 225 healthy controls from Kashmir were recruited. These include 81 men and 139 women for cases and 93 men and 132 women for controls. The frequency of cases and controls was found to be higher in females (63.18 vs. 58.66) as compared to males (36.81 vs. 41.33 ) and in the age group of $27-37$ years old $(31.81 \%$ and $32.44 \%)$ respectively. Overweight/obese subjects with an increased basal metabolic index (BMI) were seen to be at higher risk of developing hypothyroidism. Subjects who consume goitrogenic food like turnip, cauliflower, soy, etc. were also observed to be at higher risk of developing hypothyroidism as compared to those who do not consume such food item/s. The screening of the TPO gene at locus 229 resulted in 3 genotypes; CC, CT, and TT. The frequency of these genotypes was $65.7 \%$ (CC), $20.13 \%$ (CT) and $14.09 \%$ (TT). The frequency of variant genotypes (CT + TT) was significantly higher in cases as compared with that in the healthy control group $(\mathrm{O} . \mathrm{R}=1.62,95 \% \mathrm{CI}=1.07-2.43, \mathrm{P}=0.02)$. The frequency of $\mathrm{T}$ allele was seen to be significantly higher in hypothyroidic cases as compared to healthy controls, suggesting that the subjects carrying at least one $\mathrm{T}$ allele had an increased risk for the development of hypothyroidism compared with subjects carrying the $\mathrm{C}$ allele $(\mathrm{O} . \mathrm{R}=1.57,95 \% \mathrm{CI}=1.13-2.17, \mathrm{P}=0.008)$. As TT genotype was relatively infrequent, it was combined with CT genotype as a group for analysis. The distribution of the TPO genotypes and allelic frequencies between hypothyroidic cases and healthy control subjects are shown in Table 2. 
Analyzing the effect of the TPO genotypes by stratifying it against potential variables such as gender, age, dwelling, smoking status, goitrogenic food consumption, etc. Statistically significant results were obtained between this gene polymorphism and age group of 16-59 years old, both genders, smoking, goitrogenic food consumers, high basal metabolic index, urban dwelling. On the contrary, no statistically significant results were obtained for 60-70 years old age group, subjects with low basal metabolic index and other important factors determining predisposition to this type of thyroid disorder. Table $3 \& 4$ shows an association between TPO genotypes T2229C and different clinical risk factors.

Table 2: - Genotypic and allelic frequencies of TPO gene codon T2229C between the hypothyroidic cases and healthy controls.

\begin{tabular}{|l|l|l|l|l|l|}
\hline Genotypes & $\begin{array}{l}\text { Cases } \mathbf{N = 2 2 0} \\
(\boldsymbol{\%})\end{array}$ & $\begin{array}{l}\text { Controls } \\
\mathbf{N = 2 2 5}(\boldsymbol{\%})\end{array}$ & ${ }^{*} \chi^{\mathbf{2}}$ & ${ }^{\mathbf{a}}$ OR (95\% CI) & P value \\
\hline Wild (CC) & $142(65.7)$ & $168(78.6)$ & - & Referent & - \\
\hline Heterozygous (CT) & $47(20.13)$ & $36(14.4)$ & 2.65 & $1.54(0.95-2.51)$ & 0.10 \\
\hline Mutant (TT) & $31(14.09)$ & $21(6.8)$ & 2.87 & $1.74(0.97-3.17)$ & 0.09 \\
\hline Variants (CT+ GT) & $78(34.2)$ & $57(21.3)$ & 4.92 & $1.62(1.07-2.43)$ & 0.02 \\
\hline C allele & $331(75.8)$ & $372(86.14)$ & - & Referent & - \\
\hline T allele & $109(24.16)$ & $78(13.8)$ & 6.97 & $1.57(1.13-2.17)$ & 0.008 \\
\hline Total & 440 & 450 & & & \\
\hline
\end{tabular}

a; OR - Odds Ratio.

b; CI - Confidence Interval.

$* ; \chi^{2}-$ Chi square test.

Table 3: - Genotypic and allelic frequencies of TPO gene codon T2229Camong hypothyroidic cases and healthy controls stratified by different age groups.

\begin{tabular}{|c|c|c|c|c|c|}
\hline Genotypes/Variables & $\begin{array}{c}\text { Cases } N=220 \\
(\%)\end{array}$ & $\begin{array}{c}\text { Controls } \\
\mathrm{N}=225(\%)\end{array}$ & $\chi^{2}$ & $\mathrm{OR}^{\mathrm{a}}(95 \% \mathrm{CI})^{\mathrm{b}}$ & P value \\
\hline \multicolumn{6}{|c|}{16 - 26 years age group } \\
\hline Wild (CC) & $36(16.3)$ & $42(18.6)$ & - & Referent & - \\
\hline Heterozygous (CT) & $12(5.4)$ & $8(3.5)$ & 0.73 & $1.75(0.64-4.75)$ & 0.40 \\
\hline Mutant (TT) & $7(3.1)$ & $1(0.44)$ & 3.44 & $8.16(0.95-69.59)$ & 0.06 \\
\hline $\mathrm{CT}+\mathrm{TT}$ & $19(8.63)$ & $9(4.0)$ & 3.06 & $2.46(0.99-6.11)$ & 0.08 \\
\hline \multicolumn{6}{|c|}{$27-37$ years age group } \\
\hline Wild (CC) & $39(17.7)$ & $58(25.7)$ & - & Referent & - \\
\hline Heterozygous (CT) & $15(6.8)$ & $9(4.0)$ & 3.02 & $2.48(0.98-6.22)$ & 0.08 \\
\hline Mutant (TT) & $16(7.2)$ & $6(2.6)$ & 6.37 & $3.96(1.42-11.03)$ & 0.01 \\
\hline $\mathrm{CT}+\mathrm{TT}$ & $31(14.10)$ & $15(6.66)$ & 2.86 & $3.07(1.47-6.43)$ & 0.004 \\
\hline \multicolumn{6}{|c|}{$38-48$ years age group } \\
\hline Wild (CC) & $32(14.5)$ & $39(17.3)$ & - & Referent & - \\
\hline Heterozygous (CT) & $12(5.4)$ & $8(3.5)$ & 0.86 & $1.82(0.66-5.02)$ & 0.35 \\
\hline Mutant (TT) & $2(0.90)$ & $5(2.2)$ & 0.19 & $0.48(0.08-2.68)$ & 0.65 \\
\hline $\mathrm{CT}+\mathrm{TT}$ & $14(6.36)$ & $13(5.77)$ & 0.14 & $1.31(0.54-3.19)$ & 0.70 \\
\hline \multicolumn{6}{|c|}{49 - 59 years age group } \\
\hline Wild (CC) & $25(11.3)$ & $21(9.3)$ & - & Referent & - \\
\hline Heterozygous (CT) & $7(3.1)$ & $5(2.2)$ & 0.0006 & $1.17(0.32-4.25)$ & 0.93 \\
\hline Mutant (TT) & $3(1.3)$ & $7(3.1)$ & 1.09 & $0.36(0.08-1.57)$ & 0.3 \\
\hline $\mathrm{CT}+\mathrm{TT}$ & $10(4.54)$ & $12(5.33)$ & 0.18 & $0.70(0.25-1.94)$ & 0.67 \\
\hline \multicolumn{6}{|c|}{60 - 70 years age group } \\
\hline Wild (CC) & $10(4.5)$ & $8(3.5)$ & - & Referent & - \\
\hline Heterozygous (CT) & $1(0.45)$ & $6(2.6)$ & 2.01 & $0.13(0.013-1.34)$ & 0.15 \\
\hline Mutant (TT) & $3(1.3)$ & $2(0.8)$ & 0.11 & $1.20(0.16-9.01)$ & 0.74 \\
\hline $\mathrm{CT}+\mathrm{TT}$ & $4(1.81)$ & $8(3.55)$ & 0.67 & $0.40(0.08-1.82)$ & 0.41 \\
\hline
\end{tabular}

a; OR - Odds Ratio.

b; CI - Confidence Interval. 
*; $\chi^{2}$ - Chi square test.

Table 4:- Genotypic and allelic frequencies of TPO gene codon T2229Camong hypothyroidic cases and healthy controls stratified by gender, smoking, resident, Basal Metabolic Index (BMI), goitrogenic food intake, family history, boiled water intake.

\begin{tabular}{|c|c|c|c|c|c|}
\hline Genotypes/Variables & $\begin{array}{ll}\text { Cases } & \mathrm{N}=220 \\
(\%)\end{array}$ & $\begin{array}{l}\text { Controls } \\
\mathrm{N}=225(\%)\end{array}$ & $\chi^{2}$ & $\mathrm{OR}^{\mathrm{a}}(95 \% \mathrm{CI})^{\mathrm{b}}$ & $P$ value \\
\hline \multicolumn{6}{|l|}{ Gender (Male) } \\
\hline Wild (CC) & $61(27.7)$ & $75(33.3)$ & - & Referent & - \\
\hline Heterozygous (CT) & $16(7.2)$ & $11(4.8)$ & 1.34 & $1.78(0.77-4.13)$ & 0.24 \\
\hline Mutant (TT) & $4(1.81)$ & $7(3.11)$ & 0.05 & $0.70(0.19-2.51)$ & 0.81 \\
\hline $\mathrm{CT}+\mathrm{TT}$ & $20(9.10)$ & $18(8.0)$ & 0.44 & $1.36(0.66-2.81)$ & 0.50 \\
\hline \multicolumn{6}{|l|}{ Gender (Female) } \\
\hline Wild (CC) & $81(36.8)$ & $93(41.3)$ & - & Referent & - \\
\hline Heterozygous (CT) & $31(14.09)$ & $25(11.1)$ & 0.98 & $1.42(0.77-2.61)$ & 0.32 \\
\hline Mutant (TT) & $27(12.2)$ & $14(6.2)$ & 4.20 & $2.21(1.08-4.51)$ & 0.04 \\
\hline $\mathrm{CT}+\mathrm{TT}$ & $58(26.3)$ & $39(17.3)$ & 3.85 & $1.70(1.03-2.82)$ & 0.04 \\
\hline \multicolumn{6}{|l|}{ Smoke (never) } \\
\hline Wild (CC) & $101(45.9)$ & $117(52.0)$ & - & Referent & - \\
\hline Heterozygous (CT) & $29(13.18)$ & $15(6.6)$ & 4.85 & $2.24(1.13-4.41)$ & 0.27 \\
\hline Mutant (TT) & $12(5.45)$ & $5(2.2)$ & 2.81 & $2.78(0.94-8.16)$ & 0.09 \\
\hline $\mathrm{CT}+\mathrm{TT}$ & $41(18.6)$ & $20(8.8)$ & 7.50 & $2.37(1.30-4.31)$ & 0.006 \\
\hline \multicolumn{6}{|l|}{ Smoke (Moderate) } \\
\hline Wild (CC) & $35(15.90)$ & $31(13.7)$ & - & Referent & - \\
\hline Heterozygous (CT) & $10(4.5)$ & $12(5.3)$ & 0.13 & $0.74(0.28-1.94)$ & 0.71 \\
\hline Mutant (TT) & $13(5.90)$ & $14(6.2)$ & 0.04 & $0.82(0.33-2.01)$ & 0.84 \\
\hline $\mathrm{CT}+\mathrm{TT}$ & $23(10.0)$ & $26(11.5)$ & 0.21 & $0.78(0.37-1.64)$ & 0.64 \\
\hline \multicolumn{6}{|l|}{ Smoke (Heavy) } \\
\hline Wild (CC) & $6(2.7)$ & $20(8.8)$ & - & Referent & - \\
\hline Heterozygous (CT) & $8(3.6)$ & $9(4.0)$ & 1.71 & $2.96(0.79-11.08)$ & 0.19 \\
\hline Mutant (TT) & $6(2.7)$ & $2(0.88)$ & 5.12 & $10.0(1.58-63.13)$ & 0.02 \\
\hline $\mathrm{CT}+\mathrm{TT}$ & $14(6.3)$ & $11(4.8)$ & 4.50 & $4.24(1.27-14.18)$ & 0.03 \\
\hline \multicolumn{6}{|l|}{ Resident (Rural) } \\
\hline Wild (CC) & $61(27.7)$ & $74(32.8)$ & - & Referent & - \\
\hline Heterozygous (CT) & $16(7.2)$ & $19(8.4)$ & 0.018 & $1.02(0.48-2.15)$ & 0.90 \\
\hline Mutant (TT) & $9(4.09)$ & $13(5.7)$ & 0.02 & $0.84(0.33-2.18)$ & 0.88 \\
\hline $\mathrm{CT}+\mathrm{TT}$ & $25(11.3)$ & $32(14.2)$ & 9.85 & $0.94(0.50-1.76)$ & 0.99 \\
\hline \multicolumn{6}{|l|}{ Resident (Urban) } \\
\hline Wild (CC) & $81(36.8)$ & $94(41.7)$ & - & Referent & - \\
\hline Heterozygous (CT) & $31(14.09)$ & $17(7.5)$ & 4.34 & $2.11(1.09-4.10)$ & 0.03 \\
\hline Mutant (TT) & $22(10.0)$ & $8(3.5)$ & 6.45 & $3.19(1.34-7.56)$ & 0.01 \\
\hline $\mathrm{CT}+\mathrm{TT}$ & $53(24.1)$ & $25(11.1)$ & 9.31 & $2.46(1.40-4.31)$ & 0.002 \\
\hline \multicolumn{6}{|c|}{ Basal Metabolic Index (Underweight) } \\
\hline Wild (CC) & $4(1.81)$ & $3(1.3)$ & - & Referent & - \\
\hline Heterozygous (CT) & $2(0.90)$ & $2(0.88)$ & 0.16 & $0.75(0.06-8.84)$ & 0.68 \\
\hline Mutant (TT) & $1(0.45)$ & $3(1.3)$ & 0.16 & $0.25(0.01-3.77)$ & 0.68 \\
\hline $\mathrm{CT}+\mathrm{TT}$ & $3(1.36)$ & $5(2.22)$ & 0.05 & $0.45(0.05-3.57)$ & 0.80 \\
\hline \multicolumn{6}{|c|}{ Basal Metabolic Index (Normal) } \\
\hline Wild (CC) & $89(40.4)$ & $117(52.0)$ & - & Referent & - \\
\hline Heterozygous (CT) & $30(13.6)$ & $17(7.5)$ & 5.73 & $2.32(1.20-4.47)$ & 0.01 \\
\hline Mutant (TT) & $15(6.8)$ & $7(3.11)$ & 4.04 & $2.81(1.10-7.20)$ & 0.04 \\
\hline $\mathrm{CT}+\mathrm{TT}$ & $45(20.4)$ & $24(10.6)$ & 9.16 & $2.46(1.39-4.34)$ & 0.002 \\
\hline \multicolumn{6}{|c|}{ Basal Metabolic Index (Overweight) } \\
\hline Wild (CC) & $49(22.2)$ & $48(21.3)$ & - & Referent & - \\
\hline
\end{tabular}




\begin{tabular}{|c|c|c|c|c|c|}
\hline Heterozygous (CT) & $15(6.8)$ & $17(7.5)$ & 0.02 & $0.86(0.38-1.92)$ & 0.87 \\
\hline Mutant (TT) & $15(6.8)$ & $11(4.8)$ & 0.18 & $1.33(0.55-3.20)$ & 0.66 \\
\hline $\mathrm{CT}+\mathrm{TT}$ & $30(13.6)$ & $28(12.4)$ & 0.0004 & $1.05(0.54-2.01)$ & 0.98 \\
\hline \multicolumn{6}{|c|}{ Goitrogenic Food Intake (Yes) } \\
\hline Wild (CC) & $55(25.0)$ & $164(72.8)$ & - & Referent & - \\
\hline Heterozygous (CT) & $27(12.2)$ & $31(13.7)$ & 9.11 & $2.60(1.42-4.73)$ & 0.002 \\
\hline Mutant (TT) & $11(5.0)$ & $17(7.5)$ & 1.87 & $2.0(0.85-4.37)$ & 0.17 \\
\hline $\mathrm{CT}+\mathrm{TT}$ & $38(17.2)$ & $48(21.3)$ & 9.71 & $2.36(1.40-4.0)$ & 0.001 \\
\hline \multicolumn{6}{|c|}{ Goitrogenic Food Intake (No) } \\
\hline Wild (CC) & 87 (39.5) & $4(1.7)$ & - & Referent & - \\
\hline Heterozygous (CT) & $20(9.1)$ & $5(2.2)$ & 4.67 & $0.18(0.04-0.74)$ & 0.03 \\
\hline Mutant (TT) & $20(9.1)$ & $4(1.7)$ & 2.71 & $0.23(0.05-0.99)$ & 0.09 \\
\hline $\mathrm{CT}+\mathrm{TT}$ & $40(18.1)$ & $9(4.0)$ & 5.81 & $0.20(0.06-0.70)$ & 0.01 \\
\hline \multicolumn{6}{|l|}{ Family History (Yes) } \\
\hline Wild (CC) & 63 (28.6) & $35(15.5)$ & - & Referent & - \\
\hline Heterozygous (CT) & $27(12.2)$ & $15(6.6)$ & 0.037 & $1.0(0.47-2.12)$ & 0.84 \\
\hline Mutant (TT) & $6(2.7)$ & $6(2.6)$ & 0.42 & $0.55(0.16-1.85)$ & 0.51 \\
\hline $\mathrm{CT}+\mathrm{TT}$ & $33(15.0)$ & $21(9.33)$ & 0.04 & $0.87(0.44-1.73)$ & 0.83 \\
\hline \multicolumn{6}{|l|}{ Family History (No) } \\
\hline Wild (CC) & 79 (35.9) & $133(59.1)$ & - & Referent & - \\
\hline Heterozygous (CT) & $20(9.09)$ & $21(9.3)$ & 1.46 & $1.60(0.81-3.14)$ & 0.22 \\
\hline Mutant (TT) & $25(11.3)$ & $15(6.6)$ & 7.8 & $2.80(1.40-5.64)$ & 0.005 \\
\hline $\mathrm{CT}+\mathrm{TT}$ & $45(20.4)$ & $36(16.0)$ & 7.30 & $2.10(1.25-3.53)$ & 0.007 \\
\hline \multicolumn{6}{|c|}{ Boiled Water Intake (Yes) } \\
\hline Wild (CC) & $92(41.8)$ & $121(53.7)$ & - & Referent & - \\
\hline Heterozygous (CT) & $29(13.18)$ & $22(9.7)$ & 2.57 & $1.73(0.93-3.21)$ & 0.10 \\
\hline Mutant (TT) & $17(7.7)$ & $7(3.11)$ & 5.56 & $3.19(1.27-8.02)$ & 0.01 \\
\hline $\mathrm{CT}+\mathrm{TT}$ & $46(20.1)$ & $29(12.8)$ & 6.60 & $2.08(1.21-3.57)$ & 0.01 \\
\hline \multicolumn{6}{|c|}{ Boiled Water Intake (No) } \\
\hline Wild (CC) & $50(22.7)$ & $47(20.8)$ & - & Referent & - \\
\hline Heterozygous (CT) & $18(8.1)$ & $14(6.2)$ & 0.06 & $1.21(0.54-2.70)$ & 0.79 \\
\hline Mutant (TT) & $14(6.3)$ & $14(6.2)$ & 0.005 & $0.94(0.40-2.18)$ & 0.94 \\
\hline $\mathrm{CT}+\mathrm{TT}$ & $32(14.5)$ & $28(12.4)$ & 0.002 & $1.07(0.56-2.04)$ & 0.95 \\
\hline
\end{tabular}

a; OR - Odds Ratio.

$b$; $C I$ - Confidence Interval.

*; $\chi^{2}$ - Chi square test.

\section{Discussion:-}

Endocrine disorders are significant contributors to abnormal human physiological functions. Hypothyroidism is a most common type of endocrine disorder, other than diabetes mellitus (19). This study demonstrates the association between two genetic variations in the TPO gene (Thyroid peroxidase) and enhanced hypothyroid susceptibility. The results suggested that there may be an increased risk of developing hypothyroidism in the presence of some alleles in the studied polymorphisms. This is the first study showing that the TPO gene codon T2229C exon 12 variant genotypes are associated with an increased risk of thyroid disorders in a Kashmiri population. The frequency of cases and controls was found to be higher in the age group of 27-37 years old (30.6\% and 31.85\%) followed by 3848 years age group $(20.0 \%$ and $20.4 \%$ ) respectively. Subjects with an increased basal metabolic index (BMI) were also seen to be at an increased risk of developing hypothyroidism. All the subjects (patients as well as healthy group) in our study were non -vegetarian, i.e., their main diet was red meat, fish, chicken, etc. According to a survey on the prevalence of thyroid disorder induced by demography and food habits in a South Indian population; the relative risk of developing a thyroid disorder is quite high in non-vegetarian population and excessive intake of iodine rich food can also lead to an auto-immune thyroid disorder. (6). Another research article reported that a highfiber diet can cause fluctuation of thyroid hormones (20). A single nucleotide polymorphism of thyroid peroxidase gene (TPO) codon T2229C was also analyzed as an approach to the association of genetic characterization with a thyroid disorder in Kashmiri population. The result suggested that the variant genotypes $(C / C+T / T)$ or the presence 
of the $\mathrm{T}$ allele in $\mathrm{T} 2229 \mathrm{C}$ polymorphism has a positive association with hypothyroidism. It was also significantly associated with different risk determinants. TPO variant genotypes (CC+TT) were observed in females, urban residents, goitrogenic food consumers as well as non-consumers, never as well as heavy smokers ( $\geq 1$ pack per day) and subjects with normal basal metabolic Index (BMI). Such distribution of vulnerable genotypes among different determinants is because of unknown biological reason. Genetic variations in thyroid peroxidase gene (TPO) in association with anti-TPO levels have been reported earlier by some studies. Anti-TPO levels can be found in over $90 \%$ of patients with autoimmune hypothyroidism and graves disease. TPO antibodies together with TG antibodies are the predominant antibodies found in autoimmune hypothyroidism $(21,22)$. In this case-control study, the results obtained by sequencing the TPO gene suggested that this gene variation is associated with an increased risk of hypothyroidism. According to a family based study, the genetic variation in the TPO gene with an increasing antiTPO level lead to congenital hypothyroidism (23). Another study reported that this genetic variation in the exon 10 of the TPO gene has an important effect on the thyroid peroxidase enzyme activity (24). Analysis of these variations in TSH levels and the gene/s responsible may be particularly important in a population at risk for abnormal TSH levels.

\section{Conclusion:-}

This is the first observational study to examine the association between the single nucleotide polymorphisms (SNP) of the TPO gene and risk of hypothyroidism in Kashmir valley. Our study demonstrated a significant association between the TPO genetic polymorphism and hypothyroidism in Kashmiri population, suggesting a possible role for TPO T2229C polymorphism in determining the risk of hypothyroidism in our valley. Specifically, this study emphasized the effect of different lifestyle and environmental factors, e.g. age, sex, smoking status, residence, food intake, BMI, etc. as the potential confounders which could modify the association between the TPO gene SNP and hypothyroidism.

\section{Acknowledgments:-}

The authors gratefully acknowledge the University of Kashmir for making it possible for us to carry out research work without any difficulty. The authors would also like to thank the technical staff of the sample collection center, SKIMS, Soura (SGR) for helping us in the procurement of samples. This work was supported by the Indian Council Of Medical Research (ICMR) by providing funds under project No. 3/1/2/33/Nut.-2012.

\section{Competing Interests:-}

The authors have declared that no competing interest exists.

\section{References:-}

1. Kirsten D. The thyroid gland: physiology and pathophysiology. Neonatal network. 2000; NN 19(8): 11-26.

2. Vijay Panicker. Genetics of thyroid functions and disease (Review article). Clin Biochem Rev. 2011; Vol 32, November 165.

3. Andersen S, Pedersen K.M, Bruun N.H, Laurberg P. Narrow individual variations in serum T(4) and T(3)in normal subjects: a clue to the understanding of subclinical thyroid disease. J Clin Endocrinol Metab. 2002; 87: 1068-72.

4. Stathatos N. Thyroid physiology. The Medical clinics of North America. 2012; 96 (2), 165-173.

5. www.medicinenet.com. emedicine Health. Retrieved on 02-07; www.medicinenet.com, \& on, M.R. 2010; Thyroid Disorder Information.

6. Nimmy N.J, Aneesh P.M, M.P, Udupi R.H, Binu K.M. A survey on the prevalence of thyroid disorder induced by demography and food habits in South Indian Population. Indian Journal of Pharmacy Practice. 2012; Volume 5, Issue 2, April-June.

7. Rama Jailkhani, Shivashankara A. Ramachandrayya, Vidya S. Patil, Sameena. A hospital-based study of the prevalence of thyroid dysfunction in Srinagar, Jammu and Kashmir state of India. Int J Med Sci Public Health. 2015; 4(2), 151-154, doi: 10.5455 .

8. Chaturvedi S, Sanjay M, Pushpa Gupta, and et al. Assessment of Iodine induced Disorders. JIMA. 2006; 94, 127-35.

9. Lidhoo M.L. Kashmiri Tribes. Srinagar, India: Meenakshi Publishers. 1992;P: 7.

10. Chandra A.K. Iodine nutritional status of school children in rural area of Howrah district in West Bengal. Indian J. Physcol Pharmacol. 2004; 48(2), 219-24. 
11. Abigail Gelb Fruzza, Carla, Demeterco-Berggren, Kenneth Lee Jones. Unawareness of the Effects of Soy Intake on the Management of Congenital Hypothyroidism. Pediatrics. 2012; 30 (3), e699-e702.

12. Panicker V, S.G Wilson, J.P Walsh, J.B Richards, S.J Brown, J.P Beilby, A.P Bremner, et al. A locus on chromosome $1 \mathrm{p} 36$ is associated with thyrotropin and thyroid function as identified by genome-wide association study." American journal of human genetics. 2010; 87(3), 430-435.

13. Libert F, et al. Thyroperoxidase, an auto-antigen with a mosaic structure made of nuclear and mitochondrial gene modules. EMBO J. 1987; 6. 4193-4196.

14. Kimura S, Kotani T, McBride OW, Umeki K, Hirai K, Nakayama T. \& Ohtaki S. Human thyroid peroxidase: complete cDNA and protein sequence, chromosome mapping, and identification of two alternately spliced mRNAs. PNAS. 1987; 84, 5555-5559.

15. Endo Y, Onogi S, Umeki K, Yamamoto I, Kotani T, Ohtaki S. \& Fujita T. Regional localization of the gene for thyroid peroxidase to human chromosome 2p25 and mouse chromosome 12C. Genomics. 1995; 25, 760-761.

16. Kimura S, Hong Y.S, Kotani T, Ohtaki S. \& Kikkawa F. Structure of the human thyroid peroxidase gene: comparison and relationship to the human myeloperoxidase gene. Biochemistry. 1989; 28, 4481-4489.

17. Nunnez J, Pommier J. Formation of thyroid hormones. Vit Horm. 1982; 39, 175-229.

18. Sambrook J.R.D. Molecular cloning: A laboratory manual. 2001.

19. Sartorius N, UstunT,B, Lecrubier Y and Wittchen H.U. Depression co- morbid with anxiety: results from the WHO study on psychological disorders in primary health care. Br J Psychiatry. 1996; 177, 38-43.

20. Hitman S, Kelly F.C. Prevalence of congenital hypothyroidism. Indian Journal of Endocrinology. 1999; 45 (4):245-9.

21. Abramowicz M.J, Targovnik H.M, Varela V, Cochaux P, Krawiec L, Pisarev M.A, Propato F.V, Juvenal G, Chester H.A. \& Vassart G. Identification of a mutation in the coding sequence of the human thyroid peroxidase gene causing congenital goiter. Journal of Clinical Investigation. 1992; 90, 1200-1204.

22. Kotani T, Umeki K, Kawano J, Suganuma T, Hishinuma A, Ieiri T. \& Harada S. Partial iodide organification defects caused by a novel mutation of the thyroid peroxidase gene in three siblings. Clinical Endocrinology. 2003; 59, 198-206.

23. Fugazzola L. et al. Monoallelic expression of mutant thyroid peroxidase allele causing total iodide organification defect. J. Clin. Endocrinol. Metab. 2003; 88, 3264-3271.

24. Bikker H, Baas F. and De Vijlder J.J. Molecular analysis of mutated thyroid peroxidase detected in patients with total iodide organification defects. Journal of Clinical Endocrinology and Metabolism. 1997; 82, 649-653. 